Agrosearch (2007) 9 No. 1\&2 $33-42$

\title{
EFFECTS OF TEN PLANT MATERIALS IN THE PRESERVATION OF STORED COWPEA AGAINST Callosobruchus maculatus F.
}

\author{
Ojiako, F.O. \\ Department of Crop Protection, Faculty of Agriculture, University of Ilorin, Nigeria. \\ Email: frankojiako@yahoo.com
}

\begin{abstract}
The potentials of the pulverized parts of ten locally available plant products compared to a conventional storage insecticide (Actellic 2\% dust) as protectants of stored cowpea, Vigna unguiculata (L.) Walp were evaluated under laboratory conditions. Each of the plant materials was tested at four rates $(2.5 \mathrm{~g}, 5.0 \mathrm{~g}$ and $10.0 \mathrm{~g} / 100 \mathrm{~g}$ seed including a control, i.e., 0.0g. Actellic dust was applied at the rate of $1.0 \mathrm{~g}$, $2.0 \mathrm{~g}$ and $3.0 \mathrm{~g} / 100 \mathrm{~g}$ seed. Fifty (50) seeds from each of the treatments were infested with 5 pairs of adult weevils. Assessment was based on the emergence of the $F_{1}$ generation and seed damage (mean number of seeds with holes and the number of holes per seed). The seed damage data were used to estimate the weevil perforation index (WPI). All data were analyzed for variance at $P=0.05$. Although most of the plant materials afforded some measure of control of the insects in this experiment, only three of them, Piper guineense, Moringa oleifera and Ocimum gratissimum in that order, performed comparably well with Actellic dust. Actellic dust treated seeds had the least number of emerged adults (26.2-75.0) over the 7-month storage period, and a WPI of between 0.0 $26.7 \%$. The cumulative number of emerged adults were also significantly reduced $(40.586 .8$ insects) with WPI of between 12.2 and $44.4 \%$ and 35.490 .3 insects with WPI of $16.447 .8 \%$ in seeds treated with Piper guineense and Moringa oleifera, respectivelly. For Ocimum gratissimum, the cumulative number of emerged insects were between 85.6 and 195.0 with only the highest rate (10.0g/100g seed) having protection ability with WPI ranging between $31.748 .5 \%$. The untreated control had between 104272.7 emerged insects and an average of $100.0 \%$ WPI.
\end{abstract}

Key words: Piper guineense, Moringa oleifera, Ocimum gratissimum,actellic dust, cowpea, bruchids

Introduction

Worldwide, 2.27 million tonnes of cowpea is produced annually from some 7.7 million hectares with Africa producing $2 / 3$ of the world total in 16 countries. Nigeria produces about 850,000 tonnes annually or $37.5 \%$ of world crop (Rachie, 1985 ).

Unprotected cowpea grain stored over a six-month period may become so riddled with emergence holes made by C. maculatus (F.) as to be unusable as human food (Shikaan and Uvah, 1992). Up to $100 \%$ damage has been reported in unprotected cowpea after 3-5 months storage (Singh, 1977) due to Callosobruchus maculatus (F.). These losses due to produce infestation by storage pests are substantial and pose a real threat to food security in Nigeria and other developing countries in the tropics (Lale, 2001).

At present, synthetic insecticides are employed to control the bruchid (Oparaeke et al., 1998). However, despite the apparent "successes" of these toxic synthetic chemicals, fears of problems of toxicity (Olaifa, 1991), pest resurgence and elevation of secondary pests (Stiling, 1985), development of pesticide resistant populations (Golob, 1980); deleterious effects on 
Ojiako

populations of non-target organisms (White and Sinha, 1990), residues in food (Srivastava, 1980), high cost of most of these chemicals (Adesiyun, 1989), contamination of the environment (Carson, 1962), non-availability and the falsification and adulteration of pesticides (Adesiyun and Apeji, 1983) abound.

The search for alternatives to synthetic insecticides is a current approach world-wide and the use of natural plant products with their array of active components is the focal point (Oparaeke etal., 1998).

This study compares the efficacy of ten locally available plants and Actellic $2 \%$ dust for the control of stored cowpea seeds, Callosobruchus maculatus (F.).

\section{Insect Culture}

\section{Materials and Methods}

Adult Callosobruchus maculatus were collected from infested cowpea seeds from a local market in Ilorin, Kwara State, Nigeria. Insects were introduced into eight (8) breeding containers under ambient temperature of $28 \pm 3 \%$ and Relative Humidity of $75 \pm 5 \%$. These were used to establish a laboratory culture.

\section{Cowpea Seeds}

Some quantities of untreated cowpea seeds, Vigna unguiculata (L) Walp cv TVU 3629, were collected from the International Institute for Tropical Agriculture (IITA), Ibadan, Nigeria. The seeds were air- dried to avoid mouldiness after which they were sorted, sealed in cellophane bags and put in a deep freezer (for 2 weeks) for thorough disinfestation. The seeds were air-dried in the laboratory for 4 hours prior to use. One hundred (100)g of seeds were weighed out into $250 \mathrm{mls}$ translucent plastic tubes, which were covered with clean baft cloth to allow inflow of air and to mimic storage conditions in jute bags. Each treatment was replicated 3 times giving altogether 132 tubes.

\section{Preparation of Test Materials}

Fresh leaves of siam weed, Chromolaena odorata (L.) king and Robinson; lemon grass, Cymbopogon citratus (DC.) Staph, pitanga cherry, Eugenia uniflora L; Mango, Mangifera indica L; bitter gourd, Mormodica charantia L, and basil, Ocimum gratissimum L. The seeds of horse radish, Moringa oleifera Lam and brown pepper, Piper guineense Schum and Thonn and the barks of the cashew tree, Anacardium occidentale L. and mahogany, Khaya senegalensis ( Desr).A. Juss were collected from different locations in Ilorin, Kwara State, Nigeria.

The collected plant materials were air dried until completely dry and pulverized into fine powder, sieved with a 10-micron sieve and sealed in cellophane bags. The ground plant materials were measured out in rates of $2.5 \mathrm{~g}, 5.0 \mathrm{~g}$ and $10.0 \mathrm{~g}$ and mixed with $100 \mathrm{~g}$ of Cowpea seeds in $250 \mathrm{ml}$ plastic tubes and replicated 3 times.

Actellic $2 \%$ dust was bought from one of the agro-chemical stores in Ilorin. These were measured at the rates of $1.0 \mathrm{~g}, 2.0 \mathrm{~g}$ and $3.0 \mathrm{~g}$ for the three treatment levels.

\section{Treatment}

Twenty four (24) hours after, $100 \mathrm{~g}$ seeds in $250 \mathrm{mls}$ plastic tubes were treated with $2.5 \mathrm{~g}$, $5.0 \mathrm{~g}$ and $10.0 \mathrm{~g}$ of plant materials and $1.0 \mathrm{~g}, 2.0 \mathrm{~g}$ and $3.0 \mathrm{~g}$ of Actellic dust respectively, fifty ( $50 \backslash$ \seeds from each of the treated and untreated (control) cowpea seeds were transferred into 
Ojiako

new $100 \mathrm{ml}$ plastic tubes. The treatments were replicated 3 times including the control. Five (5) pairs of male and female $C$. maculatus were introduced into each of the plastic tubes, and covered with baft cloth tied firmly with rubber band.

\section{Data Collection}

The total number of adults emerging (dead and living) were counted on the first day emergence was noticed. On this day, all the insects, dead and living were removed from the tubes in order to distinguish them from those that would emerge later, that is at 24 hours and 48 hours. The effect of the experimental materials on emergence was checked on the day of emergence and 24 hours and 48 hours later.

Damage was assessed by the total number and distribution of holes per seed of Cowpea. The number of holes per sample of 10 randomly selected seeds of cowpea and the number of these seeds with holes were recorded for damage assessment. These were checked and recorded on the same date and time the first emerging adults were noticed.

The percentage of perforated grains was calculated as used by Singh et al. (1972).

No. of perforated grains in sample $\mathrm{X} \underline{100}$

Total number of grains sampled 1

The Weevil Perforation Index (WPI) (Fatope et al., 1995), was then calculated thus: $\mathrm{WPI}=\%$ treated cowpea grains perforated $\mathrm{X} \underline{100}$

$\%$ control cowpea perforated $\quad 1$

Weevil perforation index value exceeding 50 is regarded as enhancement of infestation by the weevil or negative protectant ability of the plant material or insecticide tested.

\section{Residual Test}

To assess the residual effect of these plant materials and Actellic dust on stored seeds, the afore mentioned procedures were repeated after the first, second, third, fourth, fifth, and sixth months of storage of the original $100 \mathrm{~g}$ seeds. Fifty (50) seeds were taken each month from the stock, placed in clean $100 \mathrm{mls}$ plastic tubes and 5 pairs of insects introduced as was the case at the commencement experiment.

\section{Adult Emergence}

\section{Results}

The adult emergence data were collected on the first day emergence was noticed, 24 and 48 hours later. The highest number of emerging insects occurred on the first day. The total cumulative emergence for commencement and months 1-6 were calculated for this analysis (Table 1).

Seeds treated with Actellic dust (26.2 75.0); Moringa oleifera (35.4 90.3) and Piper guineense (40.5 86.8) had the least number of emerged insects. Ocimum gratissimum tagged behind (79.4 195.0). The other materials were not very different, statistically, from the control (104.7 272.7). All the materials used appeared to have had significant effects between the first and fifth months, with the peak performance at the $3^{\text {rd }}$ and $4^{\text {th }}$ months. From the $5^{\text {th }}$ month, the effect of materials seemed to have considerably worn off. The control had the highest numbers of emerging adults. All other rates of application of the different materials were not significantly different. 
Ojiako

\section{Damage Assessment}

Over the 7-month period under investigation, Actellic dust had the least number of holes per seed with the lowest being at months 3 and 4 .

These were followed by Moringa oleifera and Piper guineense, which had about the same effect. Ocimum gratissimum was generally better than the remaining materials especially in months 3 and 4 (Fig 1). The rates of application followed the same pattern with the control having the highest number of holes per seed (Fig 2). The highest rate of application was marginally better than the medium and lower rates which were not particularly different from each other.

Actellic dust had the best index (protection ability) over the 7-month period. The highest damage index occurred at the $7^{\text {th }}$ month. Piper guineense came next in performance and was followed by Moringa oleifera. Their index fell below the 50\% mark for the 7 months under review. Though Ocimum gratissimum performed better than the other materials, it was only at the second month that it could be said to have over-all protection ability (Fig 3). The efficacy of the rates of application tended to decrease with time of storage (Fig 4). The highest rate performed better than the medium rate, which was marginally better than the lowest rate.

\section{Discussion}

Actellic dust inhibited the emergence of adult C. maculatus in treated samples during the 7 months of storage. As expected, it also had the least damage of cowpea seeds stored over the period, when compared with the untreated control. Actellic dust also gave the best Weevil Protection Index. It should be, however, noted that for all the indexes measured, the efficacy of Actellic dust started decreasing from the $5^{\text {th }}$ month after the commencement of the experiment. The lowest rate used $(1.0 \mathrm{~g} / 100 \mathrm{~g}$ seed) was adequate for storage of the seeds within the seven months period. These results are consistent with the earlier works of Ojiako (1990), Oparaeke et al. (1998) and Abdullahi and Mohammed (2004) who variously reported that Actellic dust offered the best control measure and prevented stored grains from damage.

Moringa oleifera consistently gave low cumulative emergence that was statistically the same as the effect of Actellic dust during the 7 months duration of the experiment and performed better than $P$. guineense in months 1,2 and 3. Throughout the duration of the experiment, $M$. oleifera had statistically the same effect on damage assessment of stored cowpea seeds as $P$. guineense with Weevil Perforation Index of between 16.4 and 47.8\%. The efficacy of $M$. oleifera in the experiment is clearly dose related with the highest rate $(10.0 \mathrm{~g} / 100 \mathrm{~g}$ seeds) performing better than the lower rates. The effect of $M$. oleifera in inhibiting/suppressing emergence and in damage control of stored cowpea seeds could be as a result of the presence of the steroidal glycoside-strophantidin, which was reported by Olayemi and Alabi (1994) as the bioactive agent. This bioactive agent has been found to completely inhibit the radial mycellial growth of Aspergillus flavus for the first 48 hours after inoculation which was comparable to the action of Fernassan D (Balogun et al.,

2004). Strophantidin has also been found to inhibit the growth of red flour beetle, Tribolium castaneum and tobacco horn worm, Manduca sexta (Wissenberg et al., 1998) and Trypanosoma cruzi in culture (Chataing et al., 1998). 
Ojiako

P. guineense gave considerably low numbers of emerged adults which were not statistically different from the action of Actellic dust and $M$. oleifera. There were also few damaged cowpea seeds stored with $P$. guineense with Weevil Protection Index of between 12.2 and $44.4 \%$. The efficacy was dose related as the highest rate $(10.0 \mathrm{~g} / 100 \mathrm{~g}$ seed $)$ gave the best protection against damage. Earlier works by Olaifa and Erhun (1988), Ojiako (1990) and Abdullahi and Mohammed (2004) variously showed that $P$. guineense seed

powder gave the lowest numbers of $\mathrm{F}_{1}$ offsprings and protected the stored seeds against damage of C. maculatus. . The striking potency of $P$. guineense could be attributable to its

guineense I component and to its pungent smell which prevents physical contact and caused suffocation among the adult weevils. P. guineense is also said to have high larvicidal effects whose effects are not clearly understood (Abdullahi and Mohammed, 2004).

Ocimum gratissimum, to some degrees, inhibited the emergence of adult $C$. maculatus. After the initial lull in the commencement of the experiment, $O$. gratissimum picked up and topped the list of the materials after Actellic dust, $M$. oleifera and $P$. guineense. The highest emergence figure (95.0 insects) was significantly lower than that of the untreated control (272. 7 insects). O. gratissimum also reasonably protected the seeds when compared with the untreated control.

The efficacy of $O$. gratissimum is dosage related as the lowest rate $(2.5 \mathrm{~g} / 100 \mathrm{~g}$ seed $)$ could not protect the treated seeds. The least WPI was $67.8 \%$ which was, however, better than the untreated seeds. The medium rate $(5.0 \mathrm{~g} / 100 \mathrm{~g}$ seed $)$ could only protect the seeds at the commencement and month 1 of the experiments whereas the highest rate $(10.0 \mathrm{~g} / 100 \mathrm{~g}$ seed $)$ protected the seeds all through the 7 months of storage. These reports are consistent with the earlier work of Oparaeke et al. (2002) who reported that cowpea seed damage was least on seeds treated with $10.0 \mathrm{~g}$ leaf powder of $O$. gratissimum per $100 \mathrm{~g}$ cowpea seed and highest on $2.5 \mathrm{~g} / 100 \mathrm{~g}$ seed (W/W). Earlier, Lajide et al. (1998) had found the leaf powders of O. bascilicum effective in protecting stored maize grains against $S$. zeamais at the highest dosage rates of $8 \mathrm{~g} / 100 \mathrm{~g}$ and $5 \mathrm{~g} / 50 \mathrm{~g}$ maize grains, respectively. Oparaeke et al. (2002) had attributed the protective ability of $O$. gratissimum to some alkaloids. Working on the efficacy of $O$. bascilicum and O. canum, Weaver et al. (1991) and Regnault and Hamraoui (1994) respectively, had implicated this alkaloid as linalool.

The total cumulative emergence for all the other plant materials A. occidentale, $C$. citratus, C. odorata, E. uniflora, K. senegalensis and M. indica ranging from 106.9257 .8 insects were basically statistically the same and did not differ significantly from the untreated control (104.7 272.7). Eugenia uniflora, however, had the lowest total cumulative emergence for the commencement and for months 1 and 4 and appeared to be better than other materials. It also protected the seeds at the highest and medium rates at the commencement of the experiment. Subsequently, however, E. uniflora did not give better protection ability when compared with the untreated

Actellic $2 \%$ dust offered the quickest control measure in the first 4 months of storing cowpea seeds. Piper guineense seed powder, a local and easily available herb, gave a steady protection of cowpea seeds over the months studied. Moringa oleifera, a highly nutritional and medicinal plant gave good protection to the seeds at relatively low concentrations while 
Ojiako

Ocimum gratissimum at only the highest rate performed well in effecting adult insect mortality and oviposition. The interactive effect of material type and rate of application was demonstrated by the higher rates of a given treatment material performing significantly better than the lower rates.

Piper guineense, Moringa oleifera and Ocimum gratissimum could be acceptable, cheap, safe and environmentally friendly alternatives to synthetic chemicals in storage.

It is recommended that the potentials of these products be further explored and that the present effort at finding cheaper, safe and locally available protectants be kept up.

\section{References}

Abdullahi, Y.M. and Mohammed, S. (2004): Assessment of the toxic potentials of some plant powders on survival and development of Callosobruchus maculatus. Afr. J. Biotechnol 3(1): 60-62.

Adesiyun, A.A. (1989): Insects, food, fibre and weeds: A prospect of control without pesticides. $34^{\text {th }}$ Inaugural Lecture of the University of Ilorin, 20 April, 1989. $33 \mathrm{pp}$.

Adesiyun, A.A. and Apeji, S.A. (1983): Pesticides used for crop protection in Nigeria A survey. A technical document prepared for the Federal Department of Pest Control Services. $75 \mathrm{pp}$.

Balogun, O.S.; Idowu, A.A. and Ojiako, F.O. (2004): Evaluation of the effects of four plant materials and Fernazzan D on the mycelial growth of Aspergillus flavus isolated from stored maize grains. The Plant Scientist 4: 105-114.

Carson, R. (1962): Silent Spring. Hamish Hamilton.

Chataing B.; Concepcion, J.L.; Lobaton, R. and Usubillaga, A. (1998): Inhibition of Trypanosoma cruzi growth in vitro by Solanum alkaloids; a comparison with Ketoconazole. Planta Med. 64:31-36.

Fatope, M.O.; Mann, A. and Takeda, Y. (1995): Cowpea weevil bioassay: A simple prescreen for plants with grain protectant effects. International Journal of Pest Management 41: 4486.

Golob, P. (1980): Report of a secondment as research training Adviser to the Crop Storage Research and Development Project, Malawi, November 1977 June 1980. Tropical Products Institute Report No R956 (A) pp. 45.

Lajide, L.; Adedire, C.O.; Muse, W.A. and Agele, S.O. (1998): Insecticidal activity of powders of some Nigerian plants against the maize weevil (Sitophilus zeamais Motsch.). ESN Occasional Publication 31: 227-235.

Lale, N.E.S. (2001): The Impact of Storage Pests on Post-Harvest Losses and Their Management in the Nigerian Agricultural System. Nig. J. Exptl. Biol. Vol. 2, No.2:231239.

Ojiako, F.O. (1990): Studies on the potentials of some indigenous plants in the preservation of stored seeds of cowpea, Vigna unguiculata (L.) WALP and Maize Zea mays L. Unpublished M. Sc. Thesis Faculty of Agriculture, University of Ilorin.

Olaifa, J.I. (1991): Assessment of Exposure of Pest Control Operators to Pesticides in Selected Centers in Nigeria. Nigeria J. of Ent. 12: 1-12.

Olaifa, J.I. and Erhun, W.O. (1988): Laboratory evaluation of Piper guineense for the protection of cowpea against Callosobruchus maculatus. Insect Sci. Applic. 1: 5559. 
Ojiako

Olayemi, A.B. and Alabi, P.O. (1994): Studies on traditional water purification using Moringa oleifera seeds. African Study Monographs 15 (3): 135142.

Oparaeke, A.M.; Dike, M.C. and Onu, I. (1998): Evaluation of seed and leaf powders of Neem (Azadirachta indica A. Juss) and Pirimiphos methyl for control of Callosobruchus maculatus (F.) in stored cowpea. ESN Occasional Publication (1998): 237-242.

Oparaeke, A.M.; Dike, M.C. and Onu, I. (2002): Control of Callosobruchus maculatus (Fab.) on stored cowpea with African Curry (Ocimum gratissimum L.) and African Bush Tea (Hyptis sauveolens Poit) Leaf Powders. Nigerian Journal of Entomology (2002) 19: 99-108.

Rachie, K.O. (1985): Introduction. In: Cowpea Research, production and utilization edited by S.R. Singh and K.O. Rachie. John Wiley \& Sons Ltd, Chichester, USA xxi xxviii.

Regnault-Roger, C. and Hamraoui. (1994): Inhibition of reproduction of Acanthoscelides obtectus Say (Coleoptera), a kidney bean (Phaseolus vulgaris) bruchid by aromatic essential oils. Crop Protection 13 (8): 624-628.

Shikaan, T.O. and Uvah, I.I. (1992): Effect of some materials on progeny development of Callosobruchus maculatus F. in established infestation on Cowpea grain at Samaru, Nigeria. Nigerian Journal of Entomology 12: 70-77.

Singh, K.; Agrawal, N.S. and Girish, G.K. (1972): Studies on the loss in weight caused by Sitophilus oryzae Linn. (Coleoptera: Curculionidae) to various high yielding varieties of wheat. Bull. Grain Technol. 10 (4): 271-275.

Singh, S.R. (1977): Cowpea cultivars resistant to insect pests in world germplasm collection. Tropical Grain Legume Bulletin 9: 1-7.

Srivastava, J.L. (1980): Pesticide residue in food grains and pest resistance to pesticides. Bull. Grain Technol. 18 (1): 65-76.

Stiling, P.D. (1985): An introduction to insect pests and their control. Macmillian Publishers Ltd, London.

Weaver, D.; Dunkel, F.V.; Ntezurubanza, L.; Jackson, L.L. and Stock, D.T. (1991): The efficacy of Linalool, a major component of freshly-milled Ocimum canum Sims (Lamiaceae) for protection against post-harvest damage of certain stored product Coleoptera. $J$. Stored Prod. Res. 27: 213-220.

White, N.D.G. and Sinha, R.N. (1990): Effect of Chloropyrifos-methyl on oat ecosystems in farm granaries. J. Econ. Entomol 83: 1128-1134.

Wissenberg, M.; Levy, A.; Svoboda, J.A. and Ishaaya, I. (1998): The effects of some Solanum steroidal alkaloids and glycoalkaloids on larvae of red flour beetle, Tribolium castaneum and the tobacco horn worm, Manduca sexta. Phytochemistry 47: 203-209. 
Ojiako

Table 1: Effects of the Plant Materials and Actellic Dust on the Cumulative Adult Emergence for 7-month period.

\begin{tabular}{|c|c|c|c|c|c|c|c|c|}
\hline \multirow{2}{*}{ Materials } & \multicolumn{8}{|c|}{ Cumulative emergence } \\
\hline & Commence & ment & Month & & Month & & Month & \\
\hline $\begin{array}{l}\text { Actellic } \\
\text { dust }\end{array}$ & 39.8 & $\mathrm{a}$ & 26.2 & $\bar{a}$ & 38.5 & $\bar{a}$ & 75.0 & $\mathrm{a}$ \\
\hline $\begin{array}{l}\text { Anacardium } \\
\text { occidentale }\end{array}$ & 146.2 & cde & 95.0 & bcd & 205.2 & $\mathrm{c}$ & 217.5 & $\mathrm{c}$ \\
\hline $\begin{array}{l}\text { Cymbopogon } \\
\text { citratus }\end{array}$ & 136.5 & bcd & 128.7 & ef & 170.8 & $\mathrm{c}$ & 257.8 & $\mathrm{e}$ \\
\hline $\begin{array}{l}\text { Chromolaena } \\
\text { odorata }\end{array}$ & 121.3 & $\mathrm{bc}$ & 140.7 & $\mathrm{f}$ & 189.7 & $\mathrm{c}$ & 237.3 & cde \\
\hline $\begin{array}{l}\text { Eugenia } \\
\text { uniflora }\end{array}$ & 106.9 & $\mathrm{~b}$ & 109.5 & cde & 165.2 & $\mathrm{c}$ & 237.7 & cde \\
\hline $\begin{array}{l}\text { Khaya } \\
\text { senegalensis }\end{array}$ & 158.5 & de & 82.8 & $\mathrm{~b}$ & 184.5 & $\mathrm{c}$ & 231.3 & $\mathrm{~cd}$ \\
\hline $\begin{array}{l}\text { Mormodica } \\
\text { charantia }\end{array}$ & 134.5 & bcd & 116.2 & def & 182.7 & $\mathrm{c}$ & 239.2 & cde \\
\hline $\begin{array}{l}\text { Mangifera } \\
\text { indica }\end{array}$ & 166.9 & $\mathrm{e}$ & 126.5 & ef & 189.7 & $\mathrm{c}$ & 244.7 & de \\
\hline $\begin{array}{l}\text { Moringa } \\
\text { oleifera }\end{array}$ & 56.1 & $\mathrm{a}$ & 35.4 & $\mathrm{a}$ & 49.6 & $\mathrm{a}$ & 90.3 & $\mathrm{a}$ \\
\hline $\begin{array}{l}\text { Ocimum } \\
\text { gratissimum }\end{array}$ & 127.6 & $\mathrm{bc}$ & 85.6 & bc & 117.9 & $\mathrm{~b}$ & 195.0 & $\mathrm{~b}$ \\
\hline $\begin{array}{l}\text { Piper } \\
\text { guineense }\end{array}$ & 56.1 & $\mathrm{a}$ & 40.5 & $\mathrm{a}$ & 49.4 & $\mathrm{a}$ & 86.8 & $\mathrm{a}$ \\
\hline S.E.M. & 9.64 & & 8.15 & & 14.20 & & 7.95 & \\
\hline $\begin{array}{l}\text { Rate of } \\
\text { Application }\end{array}$ & & & . & & & & & \\
\hline $\begin{array}{l}0 \mathrm{~g} \\
\text { (control) }\end{array}$ & 157.0 & $\mathrm{~b}$ & 104.7 & $\mathrm{~b}$ & 152.7 & $\mathrm{~b}$ & 272.7 & $\mathrm{c}$ \\
\hline $\begin{array}{l}1.0 \mathrm{~g} \text { Actellic; } \\
2.5 \mathrm{~g} \text { plt } \\
\text { powder } \\
/ 100 \mathrm{~g} \text { seed }\end{array}$ & 104.5 & $\mathrm{a}$ & 86.6 & $\mathrm{a}$ & 144.3 & $\mathrm{ab}$ & 167.6 & $a b$ \\
\hline $\begin{array}{l}2.0 \mathrm{~g} \text { Actellic; } \\
5.0 \mathrm{~g} \text { plt } \\
\text { powder } / 100 \mathrm{~g} \\
\text { seed }\end{array}$ & 101.0 & $\mathrm{a}$ & 86.0 & $\mathrm{a}$ & 138.2 & $\mathrm{ab}$ & 171.3 & $\mathrm{~b}$ \\
\hline $\begin{array}{l}3.0 \mathrm{~g} \text { Actellic } \\
10 \mathrm{~g} \mathrm{plt} \\
\text { powder } / 100 \mathrm{~g} \\
\text { seed }\end{array}$ & 92.2 & $\mathrm{a}$ & 81.7 & $\mathrm{a}$ & 126.0 & $\mathrm{a}$ & 156.6 & $\mathrm{a}$ \\
\hline S.E.M. & 5.81 & & 4.92 & & 8.56 & & 4.79 & \\
\hline
\end{tabular}

a,b,c,d,e Means followed by the same letter(s) in each section of the same column are not significantly different at $\mathrm{P}=0.05$ 
Ojiako

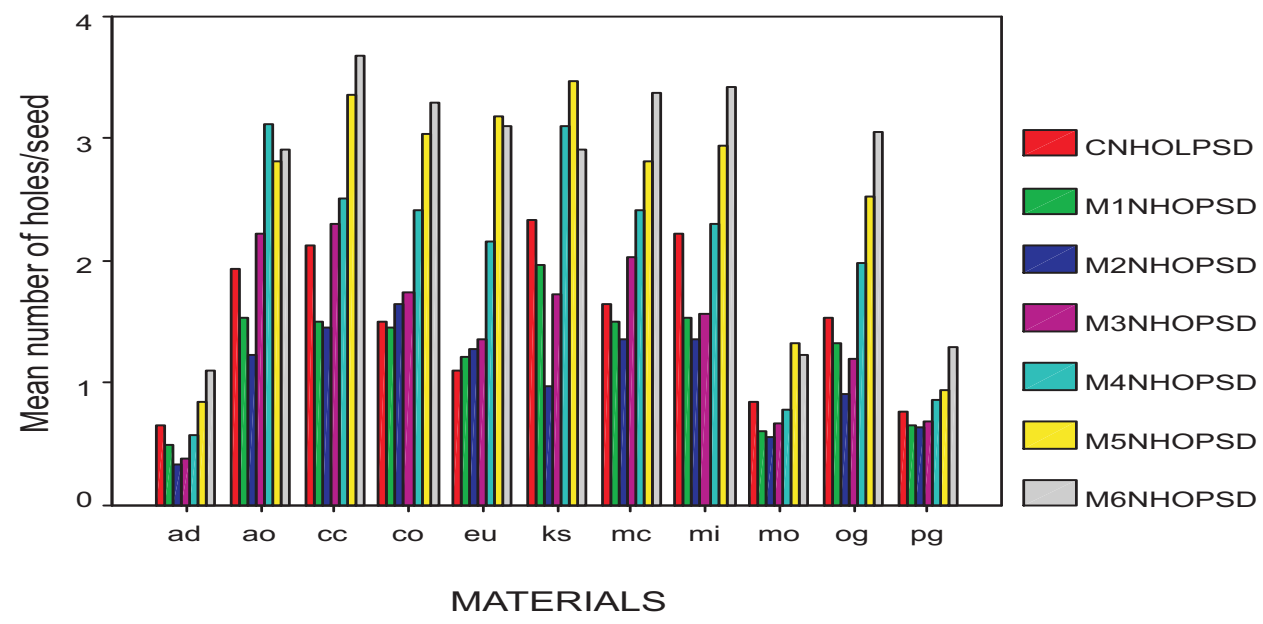

Fig : Comparative mean number of holes per seed under different

materials over a 7 month period

Fig 1: Comparative mean number of holes per seed over 7 month period under different materials

$\mathrm{C}=\mathrm{COMMENCEMENT} ; \mathrm{M} 1-\mathrm{M} 6=$ Month 1 through Month $6, \mathrm{NHOPSD}=$ Number of holes per seed,.

$\mathrm{ad}=$ Actellic Dust, $\mathrm{ao}=$ Anacardium occidentale, $\mathrm{cc}=$ Cymbopogon citratus, $\mathrm{co}=$ Chromolaena odorata, eu=Eugenia uniflora, $\mathrm{ks}=$ Khaya senegalensis, $\mathrm{mc}=$ Mormodica charantia, $\mathrm{mi}=$ Mangifera indica, $\mathrm{mo}=$ Moringa oleifera, $\mathrm{og}=$ Occimun gratissimum, $\mathrm{pg}=$ Piper guineense.

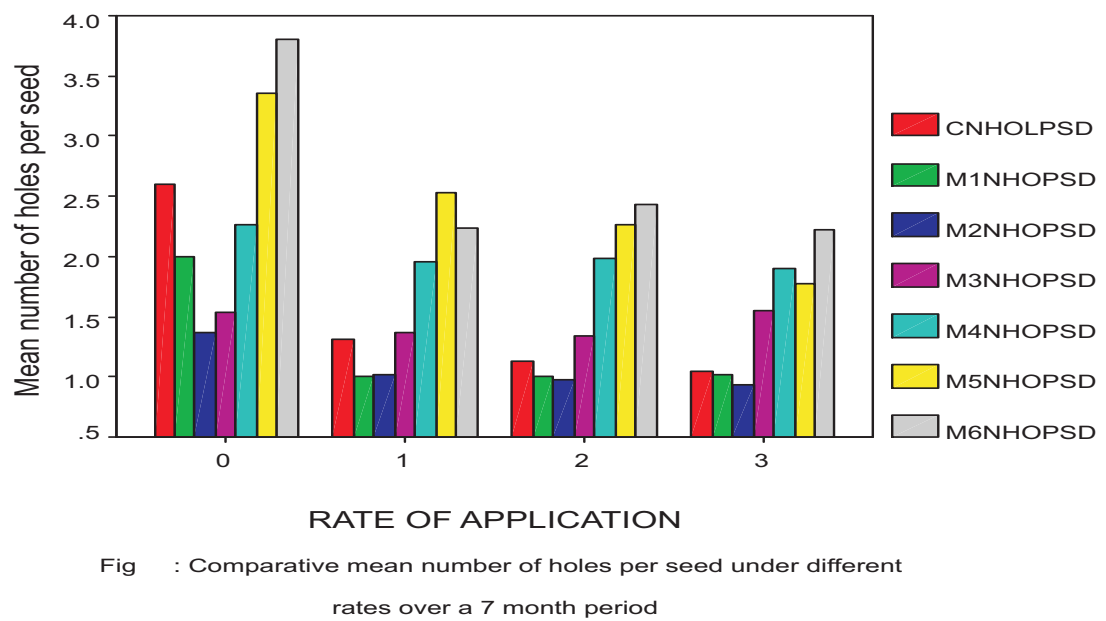

$\mathrm{C}=\mathrm{COMMENCEMENT}$; M1-M6 = Month 1 through Month 6, NHOPSD= Number of holes per seed.

Rate $0=0 \mathrm{~g} / 100 \mathrm{~g}$ seed, Rate $1=2.5 \mathrm{~g} / 100 \mathrm{~g}$ seed, Rate $2=5.0 \mathrm{~g} / 100 \mathrm{~g}$ seed, Rate $3=10.0 \mathrm{~g} / 100 \mathrm{~g}$ seed. 
Ojiako

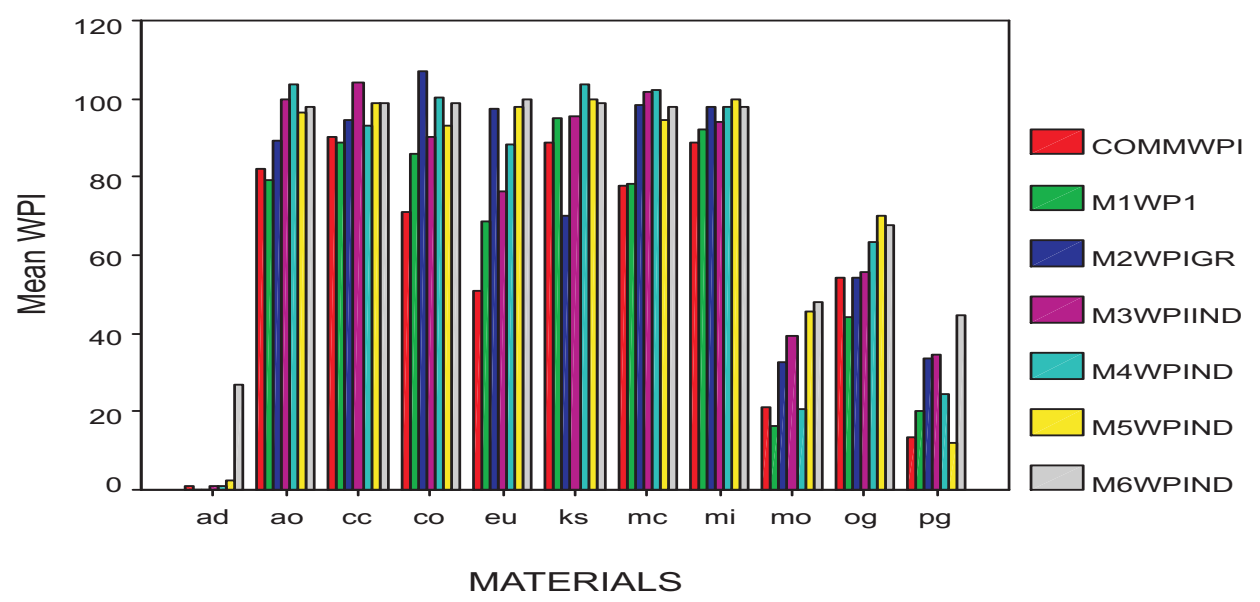

Fig : Comparative mean weevil perforation index over a seven month period under different materials

$\mathrm{C}=\mathrm{COMMENCEMENT} ; \mathrm{M} 1-\mathrm{M} 6=$ Month 1 through Month 6, WPIND= Weevil Perforation Index.

$\mathrm{ad}=$ Actellic Dust, $\mathrm{ao}=$ Anacardium occidentale, $\mathrm{cc}=$ Cymbopogon citratus, $\mathrm{co}=$ Chromolaena odorata, $\mathrm{eu}=$ Eugenia uniflora, $\mathrm{ks}=$ Khaya senegalensis, $\mathrm{mc}=$ Mormodica charantia, $\mathrm{mi}=$ Mangifera indica, $\mathrm{mo}=$ Moringa oleifera, $\mathrm{og}=$ Occimun gratissimum, $\mathrm{pg}=$ Piper guineense .

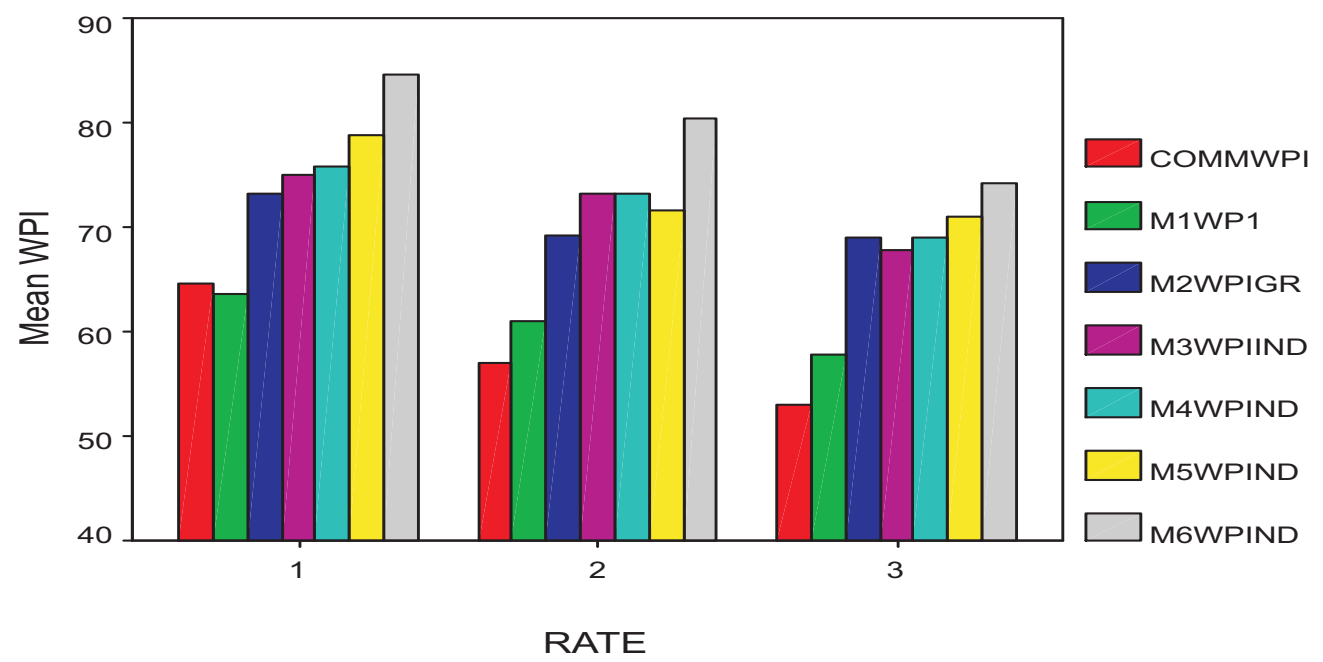

Fig : Comparative mean weevil perforation index over a seven month period under different rates

$\mathrm{C}=\mathrm{COMMENCEMENT} ; \mathrm{M} 1-\mathrm{M} 6=$ Month 1 through Month 6, WPIND= Weevil Perforation Index.

Rate $0=0 \mathrm{~g} / 100 \mathrm{~g}$ seed, Rate $1=2.5 \mathrm{~g} / 100 \mathrm{~g}$ seed, Rate $2=5.0 \mathrm{~g} / 100 \mathrm{~g}$ seed, Rate $3=10.0 \mathrm{~g} / 100 \mathrm{~g}$ seed. 